\title{
Research Paper: Assessing the Effects of Rural Tourism Branding on Improving the Quality of Life in Rural crossark Area of Iran (A Case Study of Binalud County)
}

\author{
Aliakbar Anabestani ${ }^{{ }^{*}}$ \\ 1. Professor, Geography and Rural Planning, Department of Geography, Faculty of Letters \& Humanities, Ferdowsi University of Mashhad, Mashhad, \\ Iran.
}

\begin{tabular}{|c|c|}
\hline $\begin{array}{l}\text { Use your device to scan } \\
\text { and read the article online }\end{array}$ & Crtation: Anabestani, A. (2019). Assessing the Effects of Rural Tourism Branding on Improving the Quality of Life in Ru- \\
\hline arita. & $\begin{array}{l}\text { ral Area of Iran (A Case Study of Binalud County). Journal of Sustainable Rural Development, 3(1-2), 45-62. https://doi. } \\
\text { org/10.32598/JSRD.02.02.10 }\end{array}$ \\
\hline 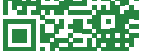 & dol: $:$ https://doi.org/10.32598/JSRD.02.02.10 \\
\hline
\end{tabular}

\section{Article info:}

Received: 19 Mar. 2019

Accepted: 20 Sep. 2019

Keywords:

Tourism brands, Appropriate infrastructure, Incentives to stay, A sense of belonging, Iran

\begin{abstract}
A B S TRACT
Purpose: Nowadays, communities intends to create brands in the field of tourism for various reasons. The most important reasons are to signalize a specific location or tourism destination in order to encourage tourists to spend more, and improve the standards and quality of life of residents. This study seeks to investigate the effects of tourism brands on the quality of rural life in the study area.

Methods: The research is an applied one conducted in a descriptive-analytical method. A major part of the data was collected using field studies and sampling (Cochran formula) from 167 households of 9263 rural households in the study area.

Results: Research findings suggest that there is a positive and $99 \%$ significant relationship between tourism brands and all components of life quality. Rural tourism development can provide villagers with incentives to stay, social justice, a sense of belonging, more benefits from the investments, services and facilities, satisfaction with living space and environmental facilities in rural areas.

Conclusion: The path analysis tests in several stages showed that 'appropriate infrastructure' as one of the indicators in the independent variable (rural tourism brand) with 40.4 percent had the most significant effect on improving the quality of rural life. This paper contributes to the literature by including various variables in the tourism brand. Therefore, this paper has a new subject and, in practical aspects, it tries to take a general assessment to find out the impact of rural brand tourism on the quality of rural life in Iran.
\end{abstract}

\section{Introduction}

Today, tourism is considered as the largest and most important industry in the world economy, so socio - economic development of countries has become so important that local, regional and national managers and planners are always planning to expand this industry (Fazelnia et al., 2015). In 
the meantime, countries try to attract more tourists than others by developing their first domestic tourism (Amani et al., 2011). Currently, in most developed countries, the development of rural tourism is realized through creating brands for rural tourism destinations, because tourism brands pave the way for competition among different service sectors; however, in a broader context it competes with other tourism destinations to attract more tourists and investment, providing better services, employment, etc. (Johansson, 2008). The tourism development in rural areas of developing countries, as one of the most effective policies for comprehensive development of rural areas, has assumed great importance $(\mathrm{Su}$, 2011). In fact, rural tourism is a valuable source of employment and income generation that could be an important tool for socio-economic development of rural communities (Samanian \& Balaly, 2013). In addition to lack of global interactions in tourism, lack of consensus on attracting tourists, and politicization of tourism, one can consider brand and branding as the greatest challenge facing tourism industry in rural areas of Iran. The review of comments on tourism made by experts of the tourism industry suggests that the application of branding concepts in Iranian tourism industry and its development have been quite inefficient. The core of Iranian tourism brand suffers fundamental weakness, and its character and position are not clearly defined; besides, due to the lack of tourism brands, lack of brand clarity and the core of brand, there have not been adequate investment and measures to improve rural tourism facilities and services (Hemmati \& Zahrani, 2014).

In the 21th century not only does the government support nation branding, but people both inside and outside of the country also get more involved in the promotion of nation branding with an approach strategy. Furthermore, private sectors are participating more in the process of nation branding through Public Private Partnership (PPP). The reason why more groups of people are turning to support nation branding is the trend of democracy spread widely, bringing about western-like political values globally (Kovathanakul, 2015). Successful branding generates customer equity, which is defined as "the totality of the brand's perceptions including the relative quality of products and services, financial performance, customer loyalty, satisfaction, and overall customer esteem towards the brand," (Desalandes \& Goldsmith, 2015).

Creating a unique brand for rural tourism and efficient planning of rural areas in the selection of appropriate projects in the field of branding can help improve the quality of rural life in different aspects (economic, social, environmental, physical and structural) (Novghani et al., 2008). Binalud County is not an exception. Studies show that considering tourism potentials of the villages of Binalud County, the number of tourists in rural areas is relatively significant and the development of tourism branding can be a major contributor to the changes in the lives of rural residents in the region. A variety of factors have widened the gap between the status quo and the favorable one, including the lack of marketing publicity, Ranjbarian et al., (2012) i.e., branding. Therefore, this research seeks to identify villages with a high potential for tourism, in line with branding and creating a tourism symbol, and then to investigate the role of brands in improving the quality of life in rural areas of the study.

One of the main approaches of the government to deprive and create development incentives to achieve the goals set in the country's 20-year vision document (which emphasizes the influx of 20 million foreign tourists annually) is to exploit the potential of deprived area. In this regard, Binaloud County has numerous villages with potential and actual potential in the field of tourism, although it faces the constraints related to financing for infrastructure development, lack of investment and sufficient number of tourists, which is due to the lack of recognition of these villages and the absence of a tourism brand. Since the destination tourism brand is the key to tourism development and a key factor in attracting tourists to tourism destinations, it is important to consider the importance of the destination brand to expand tourism in any destination. Moreover, it should not be forgotten that it is the only persuasive concept and image for the destination that draws tourists in and guarantees the profitability of the tourism industry in the long run. Therefore, the present study seeks to provide an appropriate response to the following question: to what extent has tourism brand contributed to improving the quality of life in rural areas?

\section{Literature Review}

Rural tourism brands- Rural tourism began to come into prominence in the 1950s. In the 1960s, it became economically important for local communities. During the following decades, rural tourism was considered as a tool for the development of rural communities (Jalalian et al., 2014). Rural tourism is one of the relatively good areas of rural development, which not only can create some opportunities and possibilities, especially for rural employment and income but also can play an important role in rehabilitation and modernization of rural areas (Mohammadi, 2011). In fact, rural tourism as a new subset of tourism, aiming at sustain- 
able development of local communities in rural areas, has been promoted to a means of socio-economic development and one of the most important modern jobs in rural areas (Taghdisi et al., 2015).

Many cities and locations are more inclined to tourism brands or destination brands rather than umbrella brands, as they have a stronger voice and act in a more organized way in communicating with the characteristics of various locations (Baker, 2012). Generally, tourists, especially potential tourists, do not have enough time to search about all their travel destinations. On the other hand, they will visit a place only if they logically make sure about the benefits they will achieve by visiting the place. A cleverly designed brand, promoting its message and location easily would provide the tourists with its benefits. Creating a successful brand, that can best promote a tourism destination concisely, would efficiently attract potential tourists which will result in optimal use of resources. However, creating and designing irrelevant brands would drive the tourists away, and would make their minds skeptical about the features and benefits of a location implying a waste of time and investment.

An important point in evaluating a successful brand, in the first place, is the emotional appeal of the brand. That is, to what extent the brand has succeeded to create a pleasant sensation in tourists and persuade them to visit a location. The second point is the value and validity of a city or village, and its relevance to the brand being created. In short, we can argue that brand loyalty is created based on the relationship between a location (city, village) and the visitors, and ensures that when the visitor is going to visit a place again, those places are the first ones he remembers (Mollazadeh \& Eftekharniya, 2011). The review of literature suggests that a variety of factors is effective in the formation of a brand including the existing sources of information and awareness about the destination, and the individual factors. Both sources of information and characteristics of a person are effective in the formation of a brand. The model proposed by Beerli and Martin (2004) and the one proposed by Baloglu and McCleary (1999) differentiate between the stimuli (sources of information, previous experiences and the distribution and dispersion of visits) and individual factors (demographic and psychological). Considering the general factors that bring about the formation of brands, it should be noted that the creation of tourism brands in rural areas comply with the general principles above, which include a series of economic, social and environmental factors that are outlined in the following diagram (Figure 1).

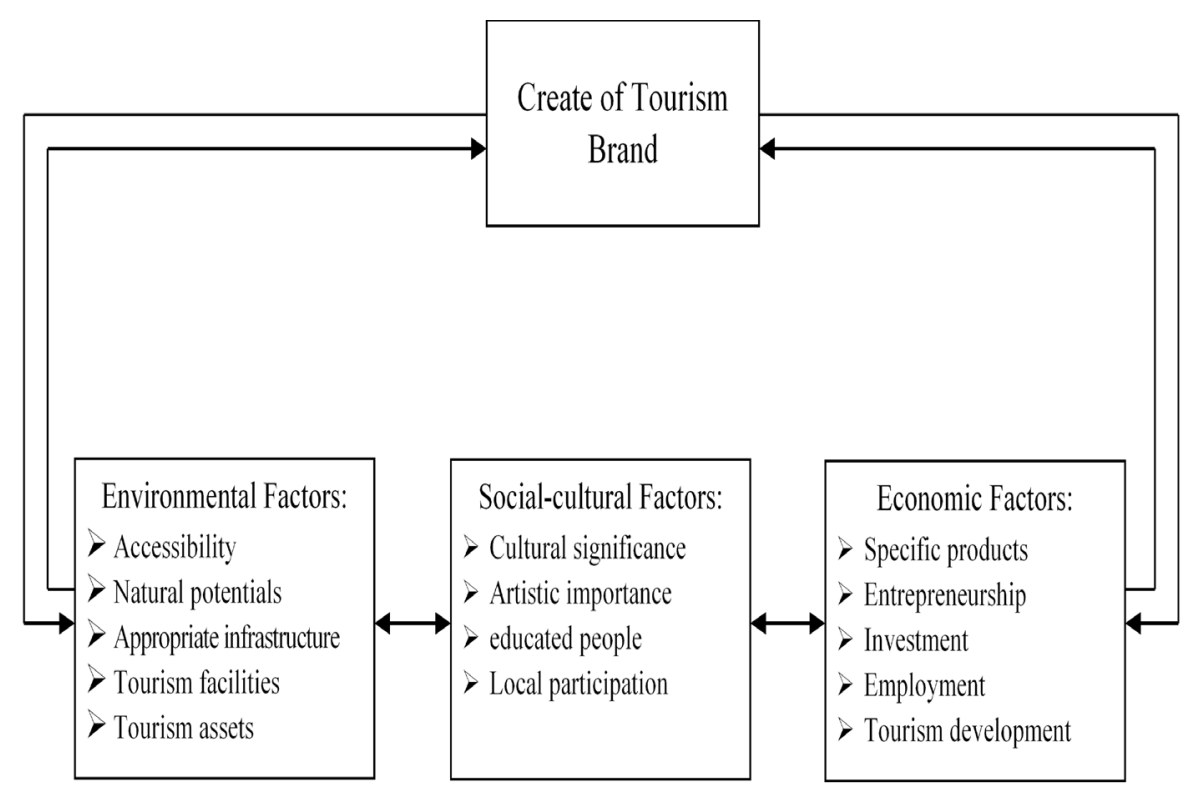

Figure 1. Factors affecting the formation of tourism brands. Source: Anabestani \& Vesal (2016) 
Quality of Life- One of the strategic objectives of sustainable rural development is to reach high quality of life. During his life, especially from the 70s onwards, one seeks to raise the quality and quantity of his life, especially its quality. We may conclude that the quality of life is both the goal and means of sustainable development. In fact, the quality of life is seen as the input and output of sustainable development. Small-scale, low density, and lack of appropriate infrastructure make it very difficult and costly to implement the policies necessary to enhance the quality of life in rural settlements (Bukenya et al., 2003). Being more essential in rural areas than others, when basic needs are reasonably satisfied, other aspects will have less effect on overall satisfaction with life which will increase the satisfaction level of rural people with their life. In fact, one of the main features of life quality is its multi-dimensionality which is accepted by all relevant experts of the world. Although many researchers have tried to identify these dimensions, they have not reached a consensus. In general, they have more common points than differences (Kord Zanganeh, 2006). Quality of life has physical, social, psychological, environmental and economic dimensions.

Given the importance of brands in tourism in urban and rural settlements, gradually assessment studies have begun to identify and establish the brands in recent years. Therefore, we have provided a summary of the study results inside and outside the country about the role of brands and branding in tourism development in rural and urban settlements and their development. In general, we can say that there has not been any certain research in the field of branding and logos and their role in improving the quality of life in rural areas of Iran.

Popescu (2009) in a study about the capabilities and backgrounds of branding in Bucharest showed that revitalization and development in a city could promote branding. Vanolo (2008) in a research on creativity image and urban initiative believes that creativity and initiatives among urban investors in Turin have caught their attention. Qu et al., (2011) in a study titled 'A model of destination branding: Integrating the concepts of the branding and destination image', showed that the overall picture was affected by three types of brand relationships which should be regarded as an important mediator between the relations of a brand and the future performance of the tourists. Gartner (2014) illustrated that the history of destination image studies is traced to its eventual evolution into destination branding. The concept of destination brand equity is then discussed as more than a simple return to a destination's marketing strategy. The case is made that destination brand equity is integrally tied to sustainability. Elliot et al., (2016) believed country brands are most influenced by the virtual dream dimension as potential travelers explore destinations online. Provincial/state brands are more influenced by the confidence factor of the comfort zone and corporate citizen dimensions. Besides, at the city level, influential brands are big and bold. Kladou et al., (2017) provided article reports on field research that operationalized the theoretical framework to examine the perceptions of visitors to Greece. Although the name is clearly more influential, the overall contribution of the symbolic elements to the brand is proven to be limited which implies that destinations need to be prioritized than other aspects of the branding effort.

Several similar studies have also been conducted in Iran, which are discussed below:

Ayoubi Yazdi and Bazrafshan (2011) in their study on the importance of brands and branding in tourist destinations showed that the branding of a tourism destination is not only about creating a logo or slogan, but also about acquiring distinctive elements of the destination in terms of brands and how these elements are related to the components of brands. These components are identity, essence, character, image, and culture. The management of the components to create a unique position of a tourism destination brand in the consumers' mind is called brand positioning. Qalamkar Moa'zem (2012) in a research on the role of Iranian villages on tourism brands showed that rural brands can act as a consultant for the planners through selecting the correct rural tourism projects which can make a way for its excellence, and turn Iranian rural tourism to an industry that is a source of income for low-income villagers. Karami and Fakhraie (2012) in a study titled "brand position in development of tourism and attracting tourists" concluded that the factors affecting the creation of a brand are: the sources of information (their volume and type), demographic factors such as age, education, psychological motivations and characteristics of the tourist destination. Barzani \& Zargham Boroujeni (2013) in a paper titled 'pathology of Iranian tourism brand' argued that there are serious problems in the core of Iranian tourism brands (consisting of the character, positioning and brand commitment) and the commitment to branding in Iran has been very poor. Sorayyaee et al., (2012) in a study titled "the effect of urban branding image on tourism behavior in of Ramsar County" concluded that the image of the destination has an intermediary role among the components like 'the image and brand relations, motivations and be- 
havioral objectives'. Shahani et al. (2013) showed that the most important factor of brand equity in Mashhad is loyalty which leads to tourist attraction with the weight of 0.320 but other factors are less effective. Anabestani $\&$ Vesal (2016) found that the economic factors had the highest coefficient of importance (54.6\%) out of the factors affecting the selection of rural tourism brands, while physical-environmental factors $(16.7 \%)$ had the lowest coefficient of importance in creating tourism brands. Hesam and Karimi (2016) in assessing the priorities of tourism destinations based on brand equity from the perspective of tourists believe that the counties of Bandar-e Anzali, Fooman, Rasht and Astara in Guilan province are of higher value tourism brand.

Based on the results of Rezavani et al. (2017) the interviews and the completed questionnaire, 5 dimensions and 22 categories for environmental quality related to branding were identified in the Hawraman region including natural dimension (with 4 categories), socio-cultural dimension (with 7 categories), economic dimension (with 1 category), physical dimension (with 5 categories), and institutional dimension (with 5 categories). Anabestani et al. (2018) showed that, from eight variables of the formation of rural tourism brand, the variables of "tourism facilities" (0. 472), "appropriate infrastructure" $(0.364)$ and" tourism development" $(0.169)$ had the greatest effect on social sustainability respectively. Rezvani et al. (2018) revealed that the factor of socio-cultural environment has the highest impact of $0.45 \%$ (Including direct and indirect), and the natural environment factor had the least effect, i.e. only $0.26 \%$, on the dependent variable (Oramanat tourist destination brand); the institutional, physical and economic factors are also $0.36,0.32$ and 0.16 respectively. The results researches of Farhadi younaki \& Anabestani (2018) show that 1- water tourism 2unique architect 3- gardens 4- eco-tourism opportunity 5- sense of belonging 6- landscape 7- rest opportunity 8- climate 9- food are prioritized as the most important variables in the formation of the destination brand of the village in Savadjan.

\section{Methodology}

Methods- The research was an applied one whose data were collected in a descriptive-survey method. The population consisted of rural households in Binalud County. According to most recent data, there were approximately 9263 rural households in Binalud County households (Statistic Center of Iran, 2016). Based on Cochran formula (with $\mathrm{p} \& \mathrm{q} 0.5$ and $\mathrm{d}$ equal 0.07 ) the sample size was comprised of 166 from 4663, and as Table 1 shows, the sample households were selected from nine villages including (Jagharq, Abrdeh-Oliya, Kang, Dehbar, Gorakhk, Abrdeh-Sofla, Zoshk Neighborhood, Hesar, Sarasiab, Azghad and Zoshk) in the previous studies, the indicators of tourism brand creation have been proven (Anabestani \& Vesal, 2016). Household was the unit of analysis in this study, but the respondent was the unit of observation. The required data were obtained through the questionnaires filled out by household members. The questionnaire designed by the authors of the study was the main research tool to collect data and asses the variables. Data processing and analysis were conducted using SPSS software. Descriptive and analytical statistical methods were employed to analyze the data. The validity of research tools was confirmed by panel from experts. On the other hand, coefficient of Cronbach's alpha is used to calculate the internal coordination tools such as questionnaires, or tests which measure different characteristics. In this study, the numerical value of this coefficient is higher than $7 \%$ (see Table 2), which shows the high compatibility and high reliability of the items of each construct.

According to exploratory studies conducted in this study, creating a successful brand that can concisely promote a place for potential tourists would efficiently attract them. Therefore, creating a rural tourism brand as an independent variable has been examined in economic, social and physical-environmental fields. In this study, the quality of life as the dependent variable, is a broad concept that has different meanings for different individuals and groups. The variable is sometimes considered as the livability of a region while others as a measurement of attractiveness. It is also interpreted as public welfare, social welfare, happiness, satisfaction, etc. for some others. (Epley et al., 2008). However, the quality of life reveals the overall social, economic and environmental characteristics in an area, a powerful tool to monitor the social development planning. Table 2 and Figure 2 shows the indicators and variables of quality of life. 
Table 1. Number of sample villages

\begin{tabular}{|cccc}
\hline Village name & Population & Household & Sample \\
\hline Jagharq & 2459 & 767 & 23 \\
\hline Abrdeh-Oliya & 3553 & 1078 & 30 \\
\hline Kang & 799 & 271 & 11 \\
\hline Dehbar & 382 & 114 & 8 \\
\hline Gorakhk & 680 & 224 & 11 \\
\hline Abrdeh-Sofla & 239 & 76 & 8 \\
\hline Zoshk Neighborhood & 350 & 112 & 8 \\
\hline Hesar & 1764 & 569 & 18 \\
\hline Sar-asiab & 1588 & 445 & 16 \\
\hline Azghad & 532 & 199 & 10 \\
\hline Zoshk & 2984 & 808 & 24 \\
\hline Total & 15330 & 4663 & 167 \\
\hline
\end{tabular}

Source: Research finding, 2018

Table 2. dependent/independent variables and their reliability

\begin{tabular}{cccc}
\hline Variable & Indicators & Number of items & Cronbach's alpha \\
\hline Tourism Brand & Total & 23 & 0.767 \\
& Incentives to stay & 3 & 0.839 \\
& Social justice & 8 & 0.784 \\
$\begin{array}{c}\text { Improvement in quality } \\
\text { of life }\end{array}$ & A sense of belonging & 3 & 0.827 \\
& Capital, services & 7 & 0.792 \\
& facilities and rural infrastructure & 6 & 0.849 \\
\hline
\end{tabular}

Source: Research finding, 2018

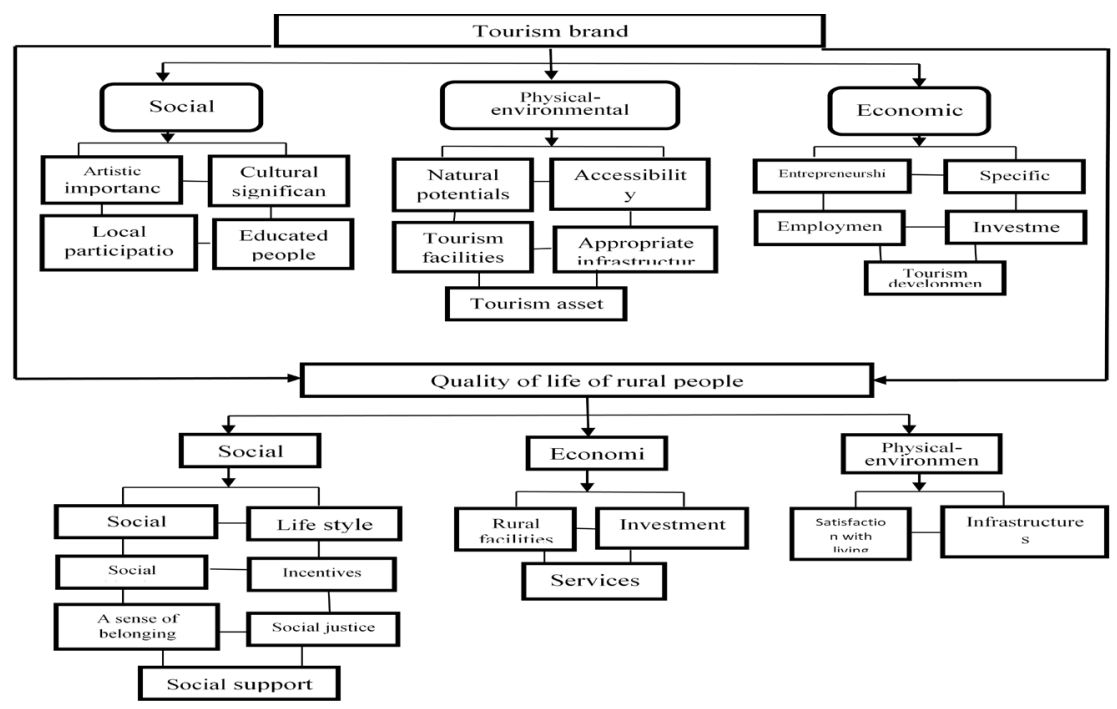

Figure 2. Analytical framework of the study. Source: Research Findings, 2018 
The study area includes Binalud County (Torghabeh and Shandiz), in the southwest of Mashhad. It is located in the northeast of Islamic republic of Iran, which shares border with Mashhad County in the north and east, with Chenaran County in the west and with Nishapur in northwest. The geographical coordinates of Binalud County are between $36^{\circ} 6^{\prime} 5^{\prime \prime}$ to $36^{\circ} 31^{\prime} 24^{\prime \prime} \mathrm{N}$ and $59^{\circ} 3^{\prime} 53^{\prime \prime}$ to $59^{\circ} 35^{\prime} 41^{\prime \prime}$ E. It has an area of about 1161 square $\mathrm{km}$, equivalent to one percent of total area of Khorasan Razavi province. Torghabeh is $4 \mathrm{~km}$ away from Mashhad, and is 1351 meters above sea level. Until 2007, Torghabeh was one of the districts of Mashhad. However, in December 2007, according to a resolution approved in board of ministers, Binalud was promoted to a County (Governor of Khorasan-e-Razavi, 2016) (Figure 3).

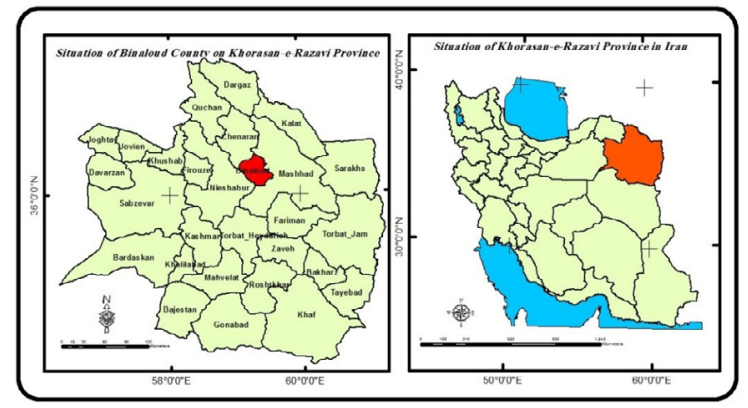

Figure 3. Location of the study area

JSRD

\section{Findings}

Questionnaire designed by the authors was the main tool for data collection and measurement of variables. Data processing and analysis was performed using SPSS software package. Statistical methods such as t-test, correlation and path analysis were used to analyze data.

\subsection{Personal Characteristics of the Participants}

A total of 167 people were selected as the population of the study from 11 villages of Jagharq rural district (Jagharq, Abrdeh-Oliya, Kang, Dehbar, Gorakhk, AbrdehSofla, and Zoshk neighborhood, Hesar, Sar-asiab, Azghad and Zoshk). 72.5\% of the respondent were men and $27.5 \%$ were women. The largest age group was 18 30 years old $(33.5 \%)$ and the smallest age group was 66 78 years old $(3.0 \%)$. The most frequent education level was junior high school (26.3\%), while the least frequent one was associate's degree $(6.0 \%)$. The most frequent type of business activity among the respondents be- longed to service jobs $(67.1 \%)$, while lowest frequency belonged to industrial ones $(3.0 \%)$.

\subsection{Improvement the Quality of Rural life}

The incentives to stay in a place show the sense of belonging to that location, a key factor for migration. Therefore, due to the importance attributed to the social dimension, 'the incentive to stay' was questioned in three items from the heads of households living in Binaloud County. The incentive to stay (head of household) with an average of $2.95 \%$ and a decrease in rural migration with an average of $2.95 \%$ have been the most effective ones. The results suggest that in social justice component, compared to other components, changes in rural lifestyle with an average of 3.28 has the highest rank. On the other hand, in 'the sense of belonging', the decrease in the sense of poverty with an average of 3.07 has had the highest average. However, in the economic dimension of improvement in the quality of life, job prospect with an average of 3.14 has the highest level. Finally, in physical-environmental dimension of improvement in the quality of life, the components of the proper utilization of natural and desirable space of the rural areas with an average of 3.05 has the highest level in the evaluations (Table 3).

\subsection{Indicators affecting Rural Tourism Branding}

According to Table 4, the heads of rural households living in the Binaloud County were questioned about the economic components of tourism branding. The results show that of total number of heads of rural households, the majority of respondents with an average of $3.62 \%$ believe that the development of tourism is the most influential economic component in creating a tourism brand. The heads of rural households living in the Binaloud County were also questioned about the social components of tourism branding. The results suggest that of total number of heads of rural households, the majority of respondents with an average of $3.48 \%$ believe that local participation is the most influential social component in creating a tourism brand. Finally, based on the views of the heads of rural households about the environmental dimension of tourism branding, the component of tourism facilities, with an average rating of $3.88 \%$ had the greatest impact on the creation of rural tourism brand. 
Table 3. Indicators of improvement in quality of life

\begin{tabular}{|c|c|c|c|c|c|c|c|}
\hline Indicators & None & Slightly & $\begin{array}{c}\text { To } \\
\text { some } \\
\text { extent }\end{array}$ & much & $\begin{array}{l}\text { Very } \\
\text { much }\end{array}$ & $\begin{array}{l}\text { Weighted } \\
\text { Average }\end{array}$ & $\begin{array}{l}\text { Chi- } \\
\text { square }\end{array}$ \\
\hline \multicolumn{8}{|c|}{ The incentives to stay } \\
\hline Rise in the incentive to stay (children), & 74 & 39 & 29 & 15 & 10 & 2.08 & 0.000 \\
\hline Decrease in rural migration, & 24 & 49 & 42 & 33 & 19 & 2.84 & 0.001 \\
\hline Rise in the incentive to stay (head of households) & 18 & 49 & 43 & 37 & 20 & 2.95 & 0.000 \\
\hline \multicolumn{8}{|c|}{ Social justice } \\
\hline $\begin{array}{l}\text { Narrowing the gap between urban and rural } \\
\text { areas }\end{array}$ & 30 & 46 & 45 & 24 & 22 & 2.77 & 0.004 \\
\hline $\begin{array}{l}\text { Sense of justice and social equality between rural } \\
\text { and urban areas }\end{array}$ & 28 & 37 & 38 & 47 & 17 & 2.92 & 0.004 \\
\hline Strengthening the social identity & 17 & 50 & 40 & 41 & 19 & 2.97 & 0.000 \\
\hline $\begin{array}{l}\text { Strengthening the social support within the rural } \\
\text { areas }\end{array}$ & 28 & 35 & 32 & 48 & 24 & 3.02 & 0.040 \\
\hline Satisfaction with social status in rural areas & 15 & 48 & 39 & 47 & 18 & 3.05 & 0.000 \\
\hline To promote solidarity among villagers & 20 & 36 & 54 & 43 & 14 & 2.97 & 0.000 \\
\hline To promote the level of rural culture & 19 & 41 & 42 & 36 & 29 & 3.08 & 0.027 \\
\hline Change in lifestyle of the villagers & 18 & 27 & 44 & 45 & 33 & 3.28 & 0.003 \\
\hline \multicolumn{8}{|c|}{ The sense of belonging } \\
\hline Decrease in sense of belonging to a rural place & 18 & 46 & 39 & 40 & 24 & 3.03 & 0.002 \\
\hline The sense of belonging to the community & 23 & 42 & 50 & 39 & 13 & 2.86 & 0.000 \\
\hline Decrease in the sense of poverty & 19 & 38 & 49 & 33 & 28 & 3.07 & 0.005 \\
\hline \multicolumn{8}{|c|}{ Capital, services and financial facilities } \\
\hline $\begin{array}{l}\text { To attract local and none-local investment to } \\
\text { increase investment in the region }\end{array}$ & 14 & 47 & 41 & 36 & 29 & 3.11 & 0.001 \\
\hline $\begin{array}{l}\text { To establish and strengthen none-governmental } \\
\text { financial and credit institutions }\end{array}$ & 26 & 43 & 41 & 36 & 21 & 2.89 & 0.027 \\
\hline Access to credit and financial services & 16 & 53 & 42 & 35 & 21 & 2.95 & 0.000 \\
\hline Satisfaction with amenities & 29 & 49 & 38 & 37 & 14 & 2.74 & 0.000 \\
\hline Rise in economic self-reliance in the rural areas & 23 & 38 & 46 & 39 & 21 & 2.98 & 0.007 \\
\hline To create incentives to improve the business & 26 & 41 & 43 & 31 & 26 & 2.94 & 0.094 \\
\hline Job prospect & 21 & 28 & 49 & 43 & 26 & 3.14 & 0.002 \\
\hline \multicolumn{8}{|c|}{ Natural environment and facilities } \\
\hline To improve communication infrastructure & 22 & 33 & 53 & 42 & 17 & 2.99 & 0.000 \\
\hline $\begin{array}{l}\text { Proper utilization of natural and desirable space } \\
\text { of the rural areas }\end{array}$ & 20 & 38 & 39 & 53 & 17 & 3.05 & 0.000 \\
\hline $\begin{array}{l}\text { Coordination between forms and formats of the } \\
\text { uses and the needs }\end{array}$ & 19 & 44 & 51 & 37 & 16 & 2.92 & 0.000 \\
\hline Decrease in the waste of water resources & 29 & 34 & 39 & 46 & 19 & 2.95 & 0.014 \\
\hline Energy saving & 30 & 44 & 42 & 35 & 16 & 2.77 & 0.005 \\
\hline Utilization of renewable energies & 84 & 36 & 26 & 11 & 10 & 1.96 & 0.000 \\
\hline
\end{tabular}


Table 4. Indicators affecting rural tourism branding

\begin{tabular}{|c|c|c|c|c|c|c|c|}
\hline Indicators & None & Slightly & $\begin{array}{l}\text { To some } \\
\text { extent }\end{array}$ & much & $\begin{array}{l}\text { Very } \\
\text { much }\end{array}$ & $\begin{array}{l}\text { Weighted } \\
\text { Average }\end{array}$ & $\begin{array}{l}\text { Chi- } \\
\text { square }\end{array}$ \\
\hline \multicolumn{8}{|c|}{ Economical } \\
\hline Specific products & 17 & 29 & 23 & 55 & 43 & 3.46 & 0.000 \\
\hline Entrepreneurship & 20 & 29 & 20 & 37 & 61 & 3.53 & 0.000 \\
\hline Investment & 48 & 28 & 30 & 30 & 31 & 2.80 & 0.000 \\
\hline Employment (type of business) & 16 & 44 & 52 & 27 & 28 & 3.04 & 0.000 \\
\hline Tourism development & 9 & 22 & 43 & 41 & 52 & 3.62 & 0.000 \\
\hline \multicolumn{8}{|c|}{ Social } \\
\hline Cultural significance & 12 & 36 & 31 & 44 & 44 & 3.43 & 0.000 \\
\hline Artistic importance & 20 & 21 & 35 & 53 & 38 & 3.12 & 0.000 \\
\hline educated people & 14 & 43 & 45 & 38 & 27 & 3.40 & 0.001 \\
\hline Local participation & 13 & 24 & 39 & 51 & 40 & 3.48 & 0.000 \\
\hline \multicolumn{8}{|c|}{ Environmental } \\
\hline Accessibility & 9 & 17 & 33 & 65 & 43 & 3.31 & 0.000 \\
\hline Natural potentials & 16 & 24 & 40 & 48 & 39 & 3.41 & 0.000 \\
\hline Appropriate infrastructure & 14 & 37 & 37 & 41 & 38 & 3.69 & 0.000 \\
\hline Tourism facilities & 5 & 16 & 35 & 48 & 63 & 3.88 & 0.000 \\
\hline Tourism assets & 25 & 26 & 35 & 44 & 37 & 3.25 & 0.006 \\
\hline
\end{tabular}

Source: Research finding, 2018

JSRD

4.3. Spatial Analysis of the Relationship between Tourism Brand and the Improvement of Rural Life Quality of Households

As Table 5 shows, in the spatial distribution of the independent variable of tourism brand in rural areas, village of Jagharq, Abrdeh-Oliya thanks to relatively more tourism facilities they have, compared to other villages, respectively with averages of 3.80 and 3.73 had the highest statistics, and the village of Gorakhk with an average of $1.81 \mathrm{had}$ the lowest statistics. Considering the spatial distribution of the average independent variables of life quality improvement (including the incentives to stay, social justice, the sense of belonging, capital, services and financial facilities) in the villages of the studying area, the villages Jagharq, Abrdeh-Oliya with the averages of 4.30 and 4.04 were in the top due to their larger area, having more facilities, and the number of tourists visiting these villages respectively. However, the villages of Gorakhk with the average of 1.22 had the lowest statistics due to remoteness and low population.

Table 5. Spatial distribution of the average of variables and indicators in each village

\begin{tabular}{|c|c|c|c|c|c|c|c|c|c|c|c|}
\hline Variable & $\begin{array}{l}\frac{\sigma}{\frac{\sigma}{\pi}} \\
\frac{\pi}{d 0} \\
\frac{\sigma 0}{\sim}\end{array}$ & 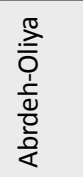 & $\begin{array}{l}\frac{100}{\sqrt{0}} \\
\stackrel{\underline{\underline{N}}}{ }\end{array}$ & 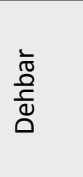 & $\begin{array}{l}\frac{}{\frac{\pi}{0}} \\
\frac{\mathrm{v}}{0} \\
\end{array}$ & 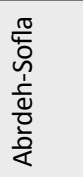 & 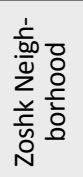 & $\begin{array}{l}\bar{\varpi} \\
\stackrel{\varpi}{I}\end{array}$ & 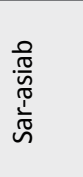 & 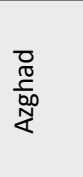 & 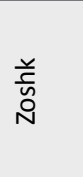 \\
\hline Quality of life & 4.30 & 4.04 & 2.75 & 2.05 & 1.22 & 2.99 & 3.12 & 3.15 & 2.90 & 3.01 & 3.30 \\
\hline Tourism brand & 3.80 & 3.73 & 2.65 & 2.44 & 1.81 & 2.14 & 2.02 & 3.16 & 2.44 & 3.19 & 3.27 \\
\hline
\end{tabular}

Source: Research finding, 2018

JSRD 
Table 6 shows the correlation between the independent variable of 'creation of rural tourism brand' and the dependent variable of improvement in life quality. As you can see, there is a positive and significant correlation between the tourism brand and all components of quality of life, at significance level of $99 \%$. The development of rural tourism can provide the inhabitants of rural areas with the incentives to stay, social justice, a sense of belonging, opportunities to take more advantage of the investment, services, facilities, and satisfaction with the living space and friendly environment. The social justice with the statistical coefficient of $0.680 \mathrm{had}$ the greatest impact on tourism brand, and the satisfaction with living space and environmental facilities with the statistical coefficient of 0.365 had the least impact.
As Table 7 shows, there is a positive and significant relationship between the creation of a tourism brand and the improved quality of life in the majority of the villages in the study area (Jagharq, Abrdeh-Oliya, Kang, Dehbar, Gorakhk, Abrdeh-Sofla, and Zoshk neighborhood, Hesar, Sar-asiab, Azghad and Zoshk). The correlation between these villages were direct and in some cases, it was relatively full. In other words, with the development of rural tourism brands, the quality of life in these villages would improve.

Table 6. the Relationship between tourism brands and improvement of life quality of rural people

\begin{tabular}{|c|c|c|c|c|c|}
\hline $\begin{array}{l}\text { Independent vari- } \\
\text { able }\end{array}$ & $\begin{array}{c}\text { dependent variable } \\
\text { (Improvement in the quality } \\
\text { of rural life) }\end{array}$ & Type of test & $\begin{array}{l}\text { Correlation } \\
\text { coefficient }\end{array}$ & Significance level & Confirmed \\
\hline \multirow{5}{*}{$\begin{array}{l}\text { Rural tourism } \\
\text { brands }\end{array}$} & The incentives to stay & Spearman & $0.479 * *$ & 0.000 & $*$ \\
\hline & Social justice & Spearman & $0.680 * *$ & 0.000 & $*$ \\
\hline & A sense of belonging & Spearman & $0.388 * *$ & 0.000 & $*$ \\
\hline & $\begin{array}{l}\text { to benefit capital, financial } \\
\text { services and facilities }\end{array}$ & Spearman & $0.494 * *$ & 0.000 & $*$ \\
\hline & $\begin{array}{l}\text { Satisfaction with living space } \\
\text { and environmental facilities }\end{array}$ & Spearman & $0.365 * *$ & 0.000 & $*$ \\
\hline
\end{tabular}

Source: Research finding, 2018

Table 7. Spatial distribution of the impacts of brands on quality of life in each village

\begin{tabular}{ccccc}
\hline Village name & Sample & $\begin{array}{c}\text { Correlation coef- } \\
\text { ficient }\end{array}$ & Significance level & Test result \\
\hline Jagharq & 23 & 0.576 & 0.004 & Significant relationship \\
\hline Abrdeh-Oliya & 30 & 0.334 & 0.003 & Significant relationship \\
\hline Kang & 11 & 0.277 & 0.004 & Significant relationship \\
\hline Dehbar & 8 & 0.271 & 0.008 & Significant relationship \\
\hline Gorakhk & 11 & 0.253 & 0.077 & - \\
\hline Abrdeh-Sofla & 8 & 0.258 & 0.022 & - \\
\hline Zoshk Neighborhood & 8 & 0.243 & 0.020 & - \\
\hline Hesar & 18 & 0.187 & 0.002 & Significant relationship \\
\hline Sar-asiab & 16 & 0.308 & 0.137 & Significant relationship \\
\hline Azghad & 10 & 0.283 & 0.003 & Significant relationship \\
\hline Zoshk & 24 & 0.178 & 0.000 & \\
\hline
\end{tabular}

Source: Research finding, 2018 
4.4. Analyzing the Effects of Tourism Brand Indicators on the Indicators of Life Quality in Rural Areas

The path analysis used for explaining the causal relationships, analyzes the correlation among the variables. Through this analysis, the direct and indirect effects of a variable on other variables are discovered. Correlation coefficients show direct and indirect effects of variables. Regression analysis has been applied at each step to determine the coefficients of a path and calculate the direct and indirect effects of variables. One of the variables (improvement in the quality of life of the villagers) is taken as a dependent variable, and other variables (factors affecting the rural tourism brands) as independent variable including 14 variables such as specific products, entrepreneurship, investment, employment (type of business), tourism development, cultural significance, artistic importance, educated people, local participation, accessibility, natural potentials, appropriate infrastructure, etc., which are used in the regression analysis so that the betas' coefficients that represent the direct effects of independent variables on the dependent variable are calculated.

\section{A) The First Stage Output:}

As the output tables show, the variables entered regression analysis, have explained $66 \%$ of the variations in the dependent variable (quality of rural life). Considering the significance of the value calculated for the coefficient of $\mathrm{F}(\mathrm{Sig}=0.000, \mathrm{~F}=21.076)$, the linear arrangement of independent variables is able to significantly explain and predict the variations in dependent variable. The significantly large coefficient of 'appropriate infrastructure' in the regression equation and its positive direction suggest that the variable of appropriate infrastructure, as an indicator of tourism brand, has considerable effects on improving the quality of life in rural areas of the study (Table 8).

\section{B) The Second Stage Output:}

The variables entering the regression analysis can explain more than 13 percent of the variations in the dependent variable (appropriate infrastructure), while in the previous model, variables remaining in the model used to explain 66 percent of the variations in the dependent variable (improvement in the quality of life). Natural potentials played a great in explaining the dependent variable. Therefore, in the third stage, the natural potentials were taken as the dependent variable and other variables as independent variables. The value of beta was calcu- lated using regression in Enter algebraic method. The results are presented in the Tables $9,10,11 \& 12$.

\section{C) The Third Stage Output:}

As the above output tables show, the variables in the regression analysis have explained $8 \%$ of the variations in the dependent variable of natural potentials. Given the significant level of the calculated value for the coefficient $\mathrm{F}(\mathrm{sig}=0.000, \mathrm{~F}=0.210)$, the linear arrangement of independent variables is significantly able to explain and predict variations in the dependent variable. As Table 13 shows, there is just 'tourism development' remaining as the last variable.

Besides, as Table 14 shows, total direct and indirect effects of the independent variable on improving the quality of rural life have been calculated. The findings from path analysis show that independent variables (rural tourism brands) in addition to direct effects have considerable indirect impacts on improving the quality of rural life. The use of this statistical technique also revealed that some variables go in different and multiple directions and indirectly affect the dependent variable (improvement in the quality of life). The variable of "natural potentials" in addition to direct effects, indirectly through the variables such as access to appropriate infrastructure, is effective in improving the quality of rural life. Furthermore, the variable of tourism development not only directly affects the improvement in the quality of life of villagers, but also indirectly affects the improvement in life quality by variables such as appropriate infrastructure, and natural potentials. On the other hand, the variables of local participation, employment and educated people have been able to directly and indirectly exert significant impacts on improving the life quality of villagers.

Eventually, the results set forth in the following table, have ranked the indicators of rural tourism brand in improving life quality on the basis of their impact. As the table shows, from 14 variables in the regression equation, the variables of appropriate infrastructure with a total impact of 0.404 , natural potentials with a total impact of 0.313, and the variable of tourism development with a total impact of 0.260 respectively ranked from first to third in terms of impacts on improving the quality of rural life. Besides, local participation, the employment opportunities associated with tourism, and educated people, ranking fourth to sixth, had major impacts on improving the indicators of life quality; however, tourism assets, tourism facilities, artistic importance, cultural significance, entrepreneurship, investment, ac- 
cessibility, and specific products, in terms of the impact on life quality, were different from other variables in the equation and have been identified as the least important factors in the analysis.

Table 8. The first model Summary: the effects of independent variables on improving the quality of life in rural areas

\begin{tabular}{cc|}
\hline Input method for variables & Algebraic (Enter) \\
\hline Coefficient of multiple correlation & R=0.812 \\
Coefficient of determination & R Square $=0.683$ \\
\hline Adjusted coefficient of determination adjusted & Adjusted R Square $=0.683$ \\
The standard error (error of correlation) & Std. Error of the Estimate $=11.76696$ \\
Analysis of Variance & $\mathrm{F}=21.076$ \\
Significance level & Sig. $=0.000$ \\
\hline Source: Research finding, 2018 & \\
\hline
\end{tabular}

Table 9. Non-standard and standard coefficients of variables of the model

\begin{tabular}{|c|c|c|c|c|}
\hline Independent Variables & $\begin{array}{l}\text { Non-standard coef- } \\
\text { ficient B }\end{array}$ & $\begin{array}{l}\text { Standard coeffi- } \\
\text { cient Beta }\end{array}$ & $\mathbf{t}$ & Significance level \\
\hline Constant number equation & 3.278 & - & 3.520 & 0.000 \\
\hline Specific products & -3.316 & -0.226 & -3.089 & 0.002 \\
\hline Entrepreneurship & 0.164 & 0.012 & 0.167 & 0.867 \\
\hline Investment & 0.128 & -0.010 & -0.180 & 0.857 \\
\hline Employment (type of business) & 2.262 & 0.143 & 2.673 & 0.008 \\
\hline Tourism development & 2.501 & 0.156 & 2.846 & 0.005 \\
\hline Cultural significance & 0.283 & 0.019 & 0.345 & 0.731 \\
\hline Artistic importance & 1.403 & 0.094 & 1.751 & 0.082 \\
\hline Educated people & 2.778 & 0.174 & 3.184 & 0.002 \\
\hline Local participation & 3.586 & 0.227 & 4.436 & 0.000 \\
\hline Accessibility & 0.719 & 0.042 & 0.77 & 0.439 \\
\hline Natural potentials & 2.663 & 0.173 & 2.908 & 0.004 \\
\hline Appropriate infrastructure & 6.112 & 0.404 & 7.352 & 0.000 \\
\hline Tourism facilities & 1.671 & 0.096 & 1.717 & 0.088 \\
\hline Tourism assets & 1.539 & 0.108 & 2.164 & 0.032 \\
\hline
\end{tabular}

Improving the quality of life $=3.728+-0.226^{*}$ Specific products $+0.143^{*}$ Employment $+0.156^{*}$ Tourism development $+0.174^{*}$ Educated people $+0.227^{*}$ Local participation $+0.173 *$ Natural potentials $+0.404 *$ Appropriate infrastructure.

Source: Research finding, 2018 
Table 10. the second model summary: the path analysis of the effects of the independent variables on appropriate infrastructure

\begin{tabular}{|c|c|c|c|c|}
\hline \multicolumn{2}{|c|}{ Input method for variables } & \multicolumn{3}{|c|}{ Algebraic (Enter) } \\
\hline \multicolumn{2}{|c|}{ Coefficient of multiple correlation } & \multicolumn{3}{|c|}{$R=0.369$} \\
\hline \multicolumn{2}{|c|}{ Coefficient of determination } & \multicolumn{3}{|c|}{ R Square $=0.136$} \\
\hline \multicolumn{2}{|c|}{ Adjusted coefficient of determination adjusted } & \multicolumn{3}{|c|}{ Adjusted R Square $=0.109$} \\
\hline \multicolumn{2}{|c|}{ The standard error (error of correlation) } & \multicolumn{3}{|c|}{ Std. Error of the Estimate $=1.20335$} \\
\hline \multicolumn{2}{|c|}{ Analysis of Variance } & \multicolumn{3}{|c|}{$F=5.065$} \\
\hline \multicolumn{2}{|c|}{ Significance level } & \multicolumn{3}{|c|}{ Sig. $=0.000$} \\
\hline \multicolumn{2}{|l|}{ Source: Research finding, 2018} & \multicolumn{3}{|r|}{ CSRD } \\
\hline Independent Variables & $\begin{array}{c}\text { Non-standard coef- } \\
\text { ficient } \\
\text { B }\end{array}$ & $\begin{array}{l}\text { Standard coeffi- } \\
\text { cient Beta }\end{array}$ & $\mathbf{t}$ & Significance level \\
\hline Constant number equation & 1.885 & - & 4.191 & 0.000 \\
\hline Employment (type of business) & 0.092 & 0.088 & 1.185 & 0.238 \\
\hline Tourism development & 0.244 & 0.231 & 3.101 & 0.002 \\
\hline educated people & -0.096 & -0.091 & -1.121 & 0.264 \\
\hline Local participation & 0.058 & 0.055 & 0.718 & 0.474 \\
\hline Natural potentials & 0.353 & 0.349 & 4.234 & 0.000 \\
\hline Tourism assets & -0.042 & -0.045 & -0.602 & 0.548 \\
\hline
\end{tabular}

Appropriate infrastructure $=1.885+0.231 *$ Tourism development $+0.349 *$ Natural potentials .

Source: Research Findings, 2018

Table 12. the third model summary: the path analysis of the effects of the independent variables on natural capabilities

\begin{tabular}{cc}
\hline Input method for variables & Algebraic (Enter) \\
\hline Coefficient of multiple correlation & $\mathrm{R}=0.242$ \\
Coefficient of determination & R Square $=0.807$ \\
Adjusted coefficient of determination adjusted & Adjusted $\mathrm{R}$ Square $=0.89$ \\
The standard error (error of correlation) & Std. Error of the Estimate $=1.26089$ \\
Analysis of Variance & $\mathrm{F}=0.210$ \\
Significance level & Sig. $=0.000$ \\
\hline
\end{tabular}

Source: Research finding, 2018

Table 13. Non-standard and standard coefficients of model variables

\begin{tabular}{ccccc}
\hline Independent Variables & $\begin{array}{c}\text { Non-standard coef- } \\
\text { ficient } \\
\text { B }\end{array}$ & $\begin{array}{c}\text { Standard coeffi- } \\
\text { cient Beta }\end{array}$ & t & Significance level \\
\hline Constant number equation & 3.307 & - & 12.577 & 0.000 \\
Tourism development & 0.037 & 0.036 & 2.458 & 0.004 \\
\hline
\end{tabular}

Natural potentials $=3.307+0.036^{*}$ Tourism development.

Source: Research finding, 2018 
Table 14. Total direct and indirect effects of independent variables on the dependent variable

\begin{tabular}{|ccccc}
\hline Independent variable & Indirect effect & Direct effect & Total & Rank \\
\hline Specific products & - & -0.0226 & -0.0226 & 14 \\
\hline Entrepreneurship & - & 0.012 & 0.012 & 11 \\
\hline Investment & - & -0.180 & -0.180 & 13 \\
\hline Employment (type of business) & 0.035 & 0.143 & 0.178 & 5 \\
\hline Tourism development & 0.104 & 0.156 & 0.260 & 3 \\
\hline Cultural significance & - & 0.019 & 0.019 & 10 \\
\hline Artistic importance & - & 0.094 & 0.094 & 8 \\
\hline educated people & -0.036 & 0.174 & 0.138 & 6 \\
\hline Local participation & 0.022 & 0.227 & 0.249 & 4 \\
\hline Accessibility & - & -0.029 & -0.029 & 12 \\
\hline Natural potentials & 0.140 & 0.173 & 0.313 & 2 \\
\hline Appropriate infrastructure & - & 0.404 & 0.404 & 1 \\
\hline Tourism facilities & - & 0.096 & 0.096 & 7 \\
\hline Tourism assets & -0.018 & 0.108 & 0.90 & 9 \\
\hline Source: Research finding, 2018 & & & & 0 \\
\hline
\end{tabular}

\section{Discussion}

The findings from this study and the previous results, Hemmati and Zahrani (2014) in the study of factors influencing satisfaction and loyalty of foreign tourists as a tourism brand, concluded that Isfahan is allowed for tourists as a tourism destination. It is concluded that the investigation of brand has needed various components such as the knowledge of destination, quality perception of the destination, value perception of the destination, the destination image and destination loyalty. Moreover, Qalamkar Moa'zem (2012) in his study argued the role emphasis on Iranian village and tourism brand that the role of rural brand in rural tourism development as a source of income for the villagers has been developed and effective and efficient step in the development of rural tourism has left a significant impact. On the other hand, Imani Khoshkhou and Ayoubi Yazdi (2010) revealed the factors affecting brand equity in the tourist destination Yazd including factors like brand loyalty, perceived quality (economic factors and the provision of services) and brand awareness of the tourist destination in which brand loyalty has the greatest influence.

In this study, the impact of indicators of rural tourism brands on improving the quality of rural life were examined. The findings showed that there has been a correlation between the independent variable of the creation of rural tourism brands and the dependent variable of improvement in quality of life. As you see, there is a positive and significant correlation ( $99 \%$ significant) be- tween tourism brand and all components of improvement in the quality of life. As the development of various kinds of rural tourism, including nomad tourism, which makes a vast majority of the rural population and production (livestock, dairy, etc.), can provide the nomads and inhabitants of rural areas with incentives to stay, social justice, a sense of belonging, opportunities to take more advantage of the investment, services, facilities, and satisfaction with the living space and friendly environment. There is a positive and significant relationship between the creation of tourism brands and the improved quality of life in most villages of the studying area. In other words, with the creation and development of rural tourism brand, the quality of life in these villages will improve. The findings and results of path analysis show that the variable of "natural potentials" in addition to direct effects, indirectly exerts effects on improving the quality of rural life, through variables such as access to appropriate infrastructure. Further, the variable of tourism development not only directly affects the improvement in the quality of rural life, but also indirectly affects the improvement in the quality of life through variables such as appropriate infrastructure, and natural potentials. On the other hand, the variables of local participation, employment and educated people have been able to directly and indirectly produce significant effects on improving the quality of rural life.

The indicators of rural tourism brands, effective in improving the quality of life have been ranked on the basis of their impacts. From 14 variables in the regres- 
sion equation, the variables of appropriate infrastructure with a total impact of $40.4 \%$, natural potentials with a total impact of $31.3 \%$, and the variable of tourism development with a total impact of $26.0 \%$ are respectively ranked from first to third in terms of the impacts on improving the quality of rural life.

Based on the research findings, the following guidelines are suggested for the development of tourism brands, which aim at improving the quality of rural life.

To draw more attention to specific products in the study area, including agronomic and horticultural products (berries, cherries, walnuts), dairy products, production of coal, stone and masonry products and wooden products at the village level to develop rural tourism brands.

To pay special attention to the entrepreneurship in rural areas in order to create new attractions in rural areas that could make way for development of tourism brands.

To provide tourism facilities in rural areas such as restaurants and guesthouses to attract more tourists in the region and develop rural tourism brands.

To recover cultural elements and give careful attention to customs that are gradually dying out, being able to create new opportunities for rural tourism brand in the region.

To take advantage of the high capabilities of the region in order to attract tourists in winter with an emphasis on the development of winter sport tourism (in line with distancing from seasonal tourism);

To strengthen and renovate tourism infrastructure and build new infrastructure in the region to enhance the quality of tourism services and reduce the bottlenecks;

To build resorts, affordable hotels, cheap guesthouses and rental houses in rural areas for the short stay of the tourists;

To take advantage of experts and well-experienced people to promote professional training in the field of tourism, including entrepreneurship based on rural tourism, to teach acceptable customs and conducts while hosting the tourists.

\section{Acknowledgements}

This research did not receive any specific grant from funding agencies in the public, commercial, or not-forprofit sectors.

\section{Conflict of Interest}

The authors declared no conflicts of interest.

\section{References}

Amani, A. R., Pourchafi, P., Qane, R. \& Fakhraie, A. (2011). Planning the development of rural tourism with SWOT Model. Paper Presented in 1st National Conference of Geography \& Rural Planning $\mathcal{E}$ Development, Mashhad, Ferdowsi University of Mashhad. [In Persian]

Anabestani, A. \& Vesal, Z. (2016). An analysis of factors affecting tourism brand creation in rural settlements (A case study of Binalud County). Journal of Tourism Planning and Development, 5(16), 148-127. [In Persian]

Anabestani, A., Abbaszadeh, M. R. \& Vesal, Z. (2018). The role of rural tourism brands on social sustainability of rural settlements (Case study: Binaloud County). Journal of Research $\mathcal{E}$ Rural Planning, 6(4), 31-48. http://dx.doi.org/10.22067/jrrp. v5i4.58483

Ayoubi Yazdi, H. \& Bazrafshan, M. (2011). The importance of brands and branding in tourist destinations. Proceeding of the 1st Conference on Management and Tourism Development, Challenges and Solutions. Retrieved 21 April 2016 from http://www. civilica.com/Paper-SHARIFURBAN01-SHARIFURBAN01_038. html. [In Persian]

Baker, B. (2012). Destination Branding for Small Cities. (2nd ed.). Creative Leap books. Portland. Oregon. USA.

Baloglu, S., \& McCleary, K. W. (1999). A model of destination image formation. Annals of Tourism Research, 26(4): 868-897.

Barzani, H. \& Zargham Boroujeni, H., (2013). A pathology of Iranian tourism brands, Modern Marketing Research, 3(1), 6380. [In Persian]

Beerli, A., \& Martin, J. D. (2004). Tourists' characteristics and the perceived image of tourist destinations: a quantitative analysis - a case study of Lanzarote, Spain. Tourism Management, 25(5), 623-636.

Bukenya, J. O., Gebremedhin, T. G., \& Schaeffer, P. V. (2003). Analysis of quality of life and rural development: evidence from West Virginia data. Growth and Change, 34(2), 202-218.

Deslandes, D. D., \& Goldsmith, R. E. (2015). Destination branding: A new concept for tourism marketing. In Proceedings of the 2002 Academy of Marketing Science (AMS) Annual Conference (pp. 130-137). Springer International Publishing.

Elliot, S., Khazaei, A., \& Durand, L. (2016). Measuring dimensions of brand influence for tourism products and places. In- 
ternational Journal of Culture, Tourism and Hospitality Research, 10(4), 396-409.

Epley, D. R., \& Menon, M. (2008). A method of assembling crosssectional indicators into a community quality of life. Social Indicators Research, 88(2), 281-296.

Farhadi Younaki, M. \& Anabestani, A. (2018). Identification of key variables in tourism destination brand formation based on futures research method (Case Study: Target village of tourism in Savadjan- Charmahal \& Bakhtyari Province). The 2nd International Conference on Modern Developments in Management Economics and Accounting. June 21, 2018, Tehran.

Fazelnia, Gh. \& M'soumi, M. (2015). The survey of villager's attitude towards the socio-economic impact of tourism lake (Case study: Lakes of Fars Province). Journal of Tourism Planning and Development, 4(14), 131-153. [In Persian]

Gartner, W. C. (2014). Brand equity in a tourism destination. Place Branding and Public Diplomacy, 10(2), 108-116.

Governor of Khorasan-e-Razavi. (2016). The latest administrative divisions, Binaloud County. Mashhad: Governor of Khorasan-eRazavi. [In Persian]

Hemmati, R. \& Zahrani, D. (2014). The factors effective in satisfaction and loyalty of foreign tourists visiting Isfahan as a tourism brand. Journal of Tourism Planning and Development, 3(10), 182-204. [In Persian]

Hesam, M. \& Karimi, S. H. (2016). Assessing priorities of tourism destinations based on brand equity from the perspective of tourists (Case study: Counties of Guilan Province). Journal of Geography, 14(49), 337-355. [In Persian]

Imani Khoshkhou, M.H. \& Ayoubi Yazdi, H. (2010). factors affecting brand equity in the tourist destination Yazd. Journal of Tourism Studies, 4(13), 113-137. [In Persian]

Jalalian, H., Namdari, F. \& Pashazadeh, A. (2014). The effects of rural tourism on development of Hajij rural area, Kermanshah. Journal of Applied Research in Geographical Sciences, 15(36), 205-228. [In Persian]

Johansson, J. (2008). Working with events to build a destination brand identity-the DMO perspective. Rapport nr.: Master Thesis 2007: 33

Karami, S. \& Fakhraie, A. (2012). Position and brand value in the development of tourism and attracting tourists. Proceedings of the 1st National Conference on Geography and Tourism in the Third Millennium, Najafabad, Islamic Azad University of Najafabad Branch. Retrieved Sept 25, 2015 from http://www. civilica.com/Paper-NGTC01-NGTC01_048.html. [In Persian]

Kladou, S., Kavaratzis, M., Rigopoulou, I., \& Salonika, E. (2017). The role of brand elements in destination branding. Journal of Destination Marketing \& Management, Article in press. http:// dx.doi.org/10.1016/i.jdmm.2016.06.011i

Kordzanganeh, J. (2006). Study of health-related quality of life in aged people who were 60 or more, (Case study: Ramhormoz City) (Unpublished master thesis). University of Tehran, Tehran, Iran. [In Persian]

Kovathanakul, D. (2015). Central Northeastern Thailand Tourism Branding, Supporting the ASEAN Economic Community. Procedia Economics and Finance, 23, 291-297.
Mohammadi, S. (2011). Rural development and tourism development. Journal of Sepehr, 20(78), 93-101. [In Persian]

Mollazadeh, A. \& Eftekharniya, M. (2011). The effects of urban branding in attracting tourists. Proceeding of the 1st International Conference on Tourism Management and Sustainable Development. Marvdasht: Islamic Azad University of Marvdasht. Retrieved 26 April 2016 from http://www.civilica. com/Paper-TMSD01-TMSD01_018.htm. [In Persian]

Novghani, M., Asgharpour Masouleh, A., Safa, Sh. \& Kermani, M. (2008). Quality of urban life and its relation with social capital in Mashhad. Journal of Social Sciences, 5(1), 111-140. [In Persian]

Popescu, R. I. (2009). The branding potential of Bucharest. Strategy and success factors. Theoretical and Empirical Researches in Urban Management, 4 (4 (13)), 177-193.

Qalamkar Moa'zem, M. (2012). The role of Iranian villages in tourism brands. Proceeding of the 1st National Conference on Tourism and Ecotourism in Iran. Hamadan, Islamic Azad University, Hamadan: Hamandishan Mohit-zist Farda Company. Retrieved 26 April 2016 from http://www.civilica. com/Paper-CTEI01-CTEI01_599.html. [In Persian]

Qu, H., Kim, L. H., \& Im, H. H. (2011). A model of destination branding: Integrating the concepts of the branding and image destination. Tourism Management, 32 (3), 465 to 476.

Ranjbarian, B., Khazaeipool, J. \& Balouie Jamkhaneh, H. (2012). An analysis of strengths, weaknesses, opportunities and threats of foreign tourism in Isfahan province using Fuzzy Analytic Hierarchy Process. Journal of Tourism Planning and Development, 1(1), 13-34. [In Persian]

Rezvani, M., Faraji Sabokbar, H., Darban Astaneh, A., Karimi, S. (2018). Analysis of factors of environmental quality effective in branding rural tourism destinations (Case study: EthnoCultural Region of Avramanat in Provinces of Kurdistan and Kermanshah). Journal of Tourism Planning and Development, 6(23), 105-136. doi: 10.22080/jtpd.2018.1766

Rezvani, M., Faraji Sabokbar, H., Darban Astaneh, A., Karimi, S. (2017). Identification and validation of effective indicators and factors of environmental quality in branding of rural tourism destinations using thematic analysis method (Case: Ethno-cultural Region of Oramanat in Kurdistan and Kermanshah Provinces). Journal of Rural Research, 8(2), 318-345. doi: 10.22059/jrur.2017.62675

Samanian, M. \& Balaly H. (2013). The socio-economic effects of rural tourism using systemic approach (Case study: Farjin Village, Hamadan), Journal of Tourism Planning and Development, 2(1), 159-180. [In Persian]

Shahni, T. J., Saeedi-mofrad, S., \& Mahdnejad, H. (2013). Brand equity of Mashhad tourism destination. Paper presented at the 7thSASTech 2013, Iran, Bandar-Abbas.

Sorayyaee, A., Radmard, M., Radmard, M. \& Yonesi, A. (2012) The effect on the behavior of urban branding image of tourism in Ramsar County. Proceedings of the 1st National Conference on Tourism and Ecotourism Iran, Hamedan, Islamic Azad University of Hamedan Branch, Retrieved Sept 26, 2015 from http://www.civilica.com/Paper-CTEI01-CTEI01_100.html. [In Persian]

Statistic Center of Iran. (2016). The results of the general census of population and housing- Binaloud County. Tehran: SCI Publication. 
Su, B. (2011). Rural tourism in China. Tourism Management, 32(6), 1438-1441.

Taghdisi, A., Varesi, H., Ahmadian, M. \& Asgari, H. (2015). Identify and analysis the factors affecting development of tourism in rural areas (Case Study: Rural Areas of Jiroft County). Journal of Research and Rural Planning, 4(9), 1-14. doi:10.22067/jrrp. v4i9.22867

Vanolo, A. (2008). The image of the creative city: Some reflections on urban branding in Turin. Cities, 25(6), 370-382. 
